\title{
Media Attention and the Market for 'Green' Consumer Products
}

\author{
John Thøgersen* \\ Aarhus School of Business, Department of Marketing and Statistics, Denmark
}

\begin{abstract}
There are signs that a general 'counter-attack' is now being orchestrated against the 'greens'. This paper surveys the evidence regarding an 'issue-attention' cycle in environmental concern in Western Europe and North America. It furthermore discusses the role of the news media in creating the cycle. It is well documented that the mass media plays an important role in determining which issues receive high or low attention by the general public. However, not only does the media's assessment of what is newsworthy mean that 'green' businesses will eventually lose the current of a rising issue attention cycle, but also its mere success means that stories framing 'green' businesses in a negative light become newsworthy while positive stories lose their newsworthiness. Therefore, and despite a large and loyal customer base, many 'green' companies now find themselves in a much more hostile environment than a decade ago. Copyright (C) 2006 John Wiley \& Sons, Ltd and ERP Environment.
\end{abstract}

Received 29 September 2004; revised 3 October 2005; accepted 19 October 2005

Keywords: media; agenda setting; issue-attention cycle; environmental concern; organic food products

\section{Introduction}

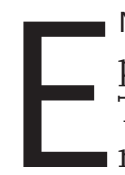

NVIRONMENTAL PROTECTION HAS BEEN AN ISSUE WITH REMARKABLE STAYING POWER ON THE public agenda in Europe and North America in the past two to three decades (Dunlap, 2002). This situation has created a favorable business climate where both new and established compaI995). Not that providing 'green' benefits has ever been a 'magical key' to consumers' hearts (and purses): far from it. Complaints about discrepancies between consumers' ('green') attitudes and their actual behavior abound.' Also, over-enthusiastic or directly deceitful 'green' claims had created a consumer 'backlash' against green marketing already in the first half of the I990s (Crane, 2000; Wong et al., I996). Further, as I will show in the following, there are signs that the tide of the media attention cycle regarding environmental issues in general and 'green' business in particular has changed, creating a more hostile climate for 'green' business. Environmental problems no longer seem to be as

\footnotetext{
* Correspondence to: John Thøgersen, Aarhus School of Business, Department of Marketing and Statistics, Haslegaardsvej 10, 8210 Aarhus V, Denmark. E-mail: jbt@asb.dk

${ }^{\mathrm{I}}$ For a sample of the complaints voiced in Danish newspapers, see Attrup, 2000; Poulsen, I999; Sønderriis, I997; Vestergaard, I998.
} 
newsworthy (Dunwoody and Griffin, I993) as they used to be (McCarthy et al., I996). Whereas 'green' NGOs and businesses earlier appeared to be some of the news media's favorite sources regarding environmental news (see, e.g., Hansen, I993; Linné, 1993), it now seems that they have become favorite targets of critique. It is the objective of this paper to summarize the evidence indicating that these changes have indeed occurred and to offer some reflections on their causes. Whatever the causes, an important consequence is that 'green' companies now find themselves in a much more hostile business environment than a decade ago. In this climate, many environmentally concerned top managers feel that it is best to keep a low profile on green issues (see, e.g., Crane, 2000), and ironically this could further amplify the downward trend in the public's attention toward environmental issues.

In the following, I first summarize the evidence suggesting an 'issue-attention' cycle (Downs, I972) in environmental concern in Western Europe and North America. Then I discuss the role of the news media in creating the salience cycle. Using the Danish organic food sector as an illustrative example, I next argue that there is reason to believe that the framing of environmental issues in general and 'green' businesses in particular has also changed. The data indicates that stories framing organic food products and producers in a favorable light have lost newsworthiness, and stories framing them as useless, deceitful and/or a lost cause are gaining. The literature on media news production suggests that this pattern is not unique, but that it is the result of inherent dynamics in the evolution and production of news (e.g. Brown and McDonald, 2000; Hilgartner and Bosk, I988). Due to this change in the media's assessment of what is newsworthy, not only are 'green' businesses bound to lose the current of a rising issue attention cycle, but they may also have to struggle against a countercurrent created by a negative press.

\section{Cycles in Environmental Concern}

When Downs (1972) introduced the term 'issue-attention cycle' to describe the observation that public attention rarely remains focused on any social problem for very long, he used the widespread upsurge of interest in the quality of the environment in the United States (and in other industrialized countries) in the late I960s and early I970s as an illustrative case. Although Downs saw reasons to expect that the environmental issue would not slip out of public attention as quickly as many other issues, he predicted that it would eventually. However, the subsequent decades tended to prove him wrong. According to most indicators, public concern for environmental issues in North America and Western Europe hardly waned during the I970s, and it revived to unprecedented heights during the I980s (making opinion researchers such as Dunlap and Scarce (I99I) speak about a 'second miracle' of public opinion). In fact, even now, three decades after Downs' (I972) article was published, public opinion polls - summarized below - indicate that environmental issues have not left the public agenda in Western Europe and North America. For example, Dunlap's (2002) analysis of opinion polls collected on a regular basis by respected pollsters $^{2}$ in the United States from the early I970s to 2002 reveals that, although there are ups and downs, a majority of Americans continue to express concern for the environment and support for tougher measures to protect the environment, as they have done at least since the early ig7os. A majority also still backs the view that protecting the environment should be given higher priority than economic growth. Truly, as Dunlap concludes, environmental protection is an issue with remarkable staying power on the public agenda.

However, if one concentrates on the most recent decade, the evolution revealed by Dunlap's (2002) data is less comforting (from an environmentalist point of view). Environmental concern and the willingness to sacrifice for the environment seem to have peaked somewhere between I990 and 1992 .

${ }^{2}$ The National Opinion Research Center, Roper, CBS News/New York Times and Gallup. 
During the I990s there was a downward trend in most indicators, and the downward trend seems to have become steeper after the turn of the millennium.

Published time series of environmental concern indicators for other industrialized countries and regions typically only cover limited segments of the three decades spanned by Dunlap's (2002) data set. ${ }^{3}$ However, together these sources provide quite solid evidence that the salience of environmental problems, or level of environmental concern, in other developed countries followed roughly the same pattern as in the USA. The major fluctuations in the issue-attention cycle, the increase in environmental concern during the I980s towards an all-time peak in the early i990s and the subsequent decline during the I990s, seem to have moved pretty much in concert in (at least) North America and Western Europe. Agenda-setting research suggests that the mass media played an important role in producing this pattern in the evolution of environmental concern.

\section{Mass Media Attention Towards Environmental Issues}

Most people would probably like to think that issues rise and fall on the public agenda in proportion to how serious the problems they represent are to society in some objective sense. However, agenda-setting research suggests that this is far from the general rule (e.g. Dearing and Rogers, I996; MacKuen and Coombs, I98I; Soroka, 2002). Many situations in society could be perceived as social problems, but they are not defined as such by the major actors influencing the agenda. ${ }^{4}$ An important reason is that there are cognitive and practical limits to how many issues a citizen can attend to simultaneously. Similarly, each of the arenas for public debate (in particular the mass media and political institutions) has a finite 'carrying capacity' (Hilgartner and Bosk, I988). Hence, public attention is a scarce good, and social problems compete for a share of it (Behr and Iyengar, I985).

Although earlier studies described the role of the mass media for the salience of social problems in the general public, it was not until the early i970s that researchers started to combine content analysis of news media and opinion and attitude survey data (McCombs and Shaw, I972). The first studies were based on synchronous correlations only, but soon followed studies of the pattern and sequence of changes in media coverage and public opinion over time, thus providing a much sounder basis for inferences about the causality of the relationship (Zucker, I978). Others used an experimental approach to test the direction of the causality (Iyengar and Kinder, I987). By the I980s it was thoroughly documented that there is a causal relationship between the issue priorities of the mass media and the salience of social problems in the public (Rogers et al., I993).

A number of these studies investigated the influence of news media on the salience of environmental issues. For instance, Ader (I995) found that the salience of environmental pollution problems in the USA in the I970-I990 period was significantly correlated with newspaper coverage of the issue in the preceding months, but not with the coverage in the following months, and Soroka (2002) found the

\footnotetext{
${ }^{3}$ Canada, I988-I995 (Soroka, 2002); Australia, I975-I995 (Pakulski et al., I998); Hong Kong, I983-I995 (Chan, I999); Sweden, I987-I996 (Bennulf, I999); The European Community, I978-I989 (Hofrichter and Reif, I990) and I986-I995 (Kramer, I998). The time series reported in the two latter sources are based on Eurobarometer surveys and they can be extended by means of more recent surveys published by Eurobarometer (see http://europa.eu.int/comm/public_opinion/standard_en.htm). Consistent with what Dunlap reports from polls in the USA, the indicator for environmental concern reported by Hofrichter and Reif (i.e. the percentage of the population expressing the opinion that 'protecting the environment and fighting pollution' is 'very important') increased to an all-time peak between I989 and I991, but fell again between I99I and I993 and continued the decline between I993 and I995. The indicator reported by Kramer (i.e. the percentage of the population expressing the opinion that 'protecting the environment and fighting pollution' is 'an immediate and urgent problem', rather than 'more a problem for the future' or 'not really a problem at all') reflects the same decline in environmental concern between the early and midI990s, and a more recent Eurobarometer survey using the same indicator found that the decline continued throughout the decade.

${ }^{4}$ This, of course, does not necessarily mean that the issues that are brought on the agenda by the news media are completely unrelated to real-world realities (see, e.g., Behr and Iyengar, I985; MacKuen and Coombs, I98I).
} 
same in Canada in the 1985-I995 period. Hence, the direction of causality can only go from media coverage to issue salience in the public, not the other way. Based, as they are, on public opinion data collected two to six times a year and covering decades, these studies speak about the long-term relationship between the coverage of issues in news media and the salience of environmental problems. A study by Brosius and Kepplinger (I990) further documents that the attention towards environmental problems reacts rather quickly to the coverage of issues in news media. Their data covered concern for the environment (and other social problems) as reflected in 53 weekly polls collected in West Germany in I986, and they used the news coverage of German prime-time TV news shows in the preceding week as the predictor.

However, not all issues are equally dependent on the mass media. In an influential paper, Zucker (I978) proposed that the impact of the news media depends on the obtrusiveness of the issue and on the duration of the public's attention to the issue. An issue is obtrusive to the degree that people have direct experience with it. The less direct experience people have with a given issue, the more they will rely on the news media for information about and interpretation of that issue. The duration of past attention towards an issue has two impacts, according to Zucker (I978). First, after some time (he suggests a couple of years) most people have already made up their minds about the issue and are, hence, less subject to being influenced by the media than when the issue is first brought up. Second, after a while people tend to get bored with an issue, unless it is really obtrusive (Henry and Gordon, 200I). Consequently, even though the problem continues to exist, media coverage may not be sufficient to maintain the issue salience (unless new spectacular events 'energize' the issue).

Most people do not directly experience most of the environmental problems confronting industrialized societies. Hence, there is reason to believe that the news media played an important role in putting environmental issues on the public agenda (Anderson, I997). On the other hand, as we saw above, environmental pollution has enjoyed high attention for a very long time, meaning that the media's influence on public opinion in this area should now be expected to be much smaller (unless spectacular events occur bringing new dimensions to the issue). A few empirical studies have tested - and confirmed these propositions.

Zucker (I978) analyzed concern for environmental pollution, among other issues, in the USA in the I968-1976 period. Consistent with the issue being classified as relatively unobtrusive, he found that the salience of environmental problems, as reflected in biannual Gallup polls, was predicted well by TV news coverage in preceding months, but only in the first four years. As predicted by the duration principle, the relationship was insignificant in the ensuing four-year period. Zucker's findings were replicated by a study in Hong Kong, analyzing the relationship between newspaper coverage of local environmental issues and the salience of environmental pollution problems from I983 to I995 (Chan, I999): in the January I983-June I988 period, newspaper coverage of environmental issues in the preceding month strongly and significantly predicted issue salience, but in the December I988 to November 1995 period the relationship between the two variables was insignificant.

The boredom explanation of the reduced media effect on issue attention after a while implies that, although new spectacular events may 'energize' the issue, they tend to do so to a diminishing degree (Brosius and Kepplinger, I992). Because of the intense competition for media and public attention, drama and novelty command a high premium (Hilgartner and Bosk, I988). Hence, issue sponsors are encouraged to cast social problems in dramatic and persuasive terms (e.g. the typical Greenpeace actions, cf. Anderson, 1997). Hilgartner and Bosk (I988) argue that if a social problem is framed in a too repetitive way, either a new frame must be found, or the problem attention will most likely undergo a decline because of its diminished dramatic value. ${ }^{5}$ Hence, sheer boredom with that particular 'public drama'

${ }^{5}$ Notice that this is not specifically a problem for environmental issues, but the conditions shared by all issues on the public agenda. 
may enable competing social problems - or perhaps even competing definitions of the same issue - to take its place on the media and public agendas.

Dunlap (2002, p. I2) suggests that the most likely reason why the environment has stayed quite high on the public agenda for three decades is that 'an endless variety of new problems, ranging from local toxic contamination and urban sprawl to global threats such as ozone depletion and climate change, have emerged and blended together to create a sense of continual deterioration'. However, research into the dynamics of issue attention suggests that the sustained bombardment with messages about similar problems eventually leads to saturation and to dedramatizing of problems of that class (Hilgartner and Bosk, I988). This means, for example, that although major oil spills, such as the one hitting the Spanish coast after the wreckage of the Prestige in November 2002 (see O'Donovan, 2003), are still considered newsworthy, they will not receive anything near the media and public attention of the Exxon Valdez accident in Alaska in $1989^{6}$ (cf. Brown and McDonald, 2000). Hence the decline in media attention and, consequently, public attention to environmental problems during the I99os.

The media's influence is not limited to which issues are on the public agenda, however. It also extends to the way the issues are framed, which has been called a 'second level' of agenda setting (see Weaver et al., 2004). Recent research has documented that by deciding which aspects of an issue to attend to the mass media influence the way people perceive the issue as a whole (e.g. McCombs et al., I997). However, to my knowledge, there are still no studies describing the importance of second-level agenda setting for public attention towards environmental issues.

Still, it seems very likely that the need for drama, and the boredom with traditional ways of framing environmental issues, not only means that environmental issues will eventually lose share of media and public attention to competing social problems. Probably, it also means that competing ways of framing environmental issues will become relatively more 'competitive'. The warm embracement by many influential news media in Europe and North America of the Danish political scientist Bjørn Lomborg's book The Skeptical Environmentalist, published by Cambridge University Press in 200I, illustrates this. ${ }^{7}$ Lomborg argues that many of the hottest environmental issues, such as global warming, overpopulation, energy, deforestation, species loss, water shortages and a variety of other issues, are exaggerated, not only by environmental pressure groups, but also by the leading scientists in the fields. On the other hand, they claim that the evidence Lomborg uses to back his arguments is a biased selection of the available empirical evidence, and that he reports the evidence in a biased way that suits his purpose. One might think that such a strong critique from some of the leading experts would make the opinions of a non-expert like Lomborg uninteresting for serious news media, but this is far from the case. In the dispute between Lomborg and the environmental science establishment, the media seems to find properties of a classical drama as reflected in the David against Goliath myth, or in H. C. Andersen's fairytale The Emperor's New Clothes (Lomborg being the little boy, of course). In the next section, I will present another illustrative example of important news media turning their back on the environmental cause, in this case confronting 'green' businesses in a more direct way.

\section{The Press and Organic Food in Denmark}

The illustrative case reports the coverage of organic food by the Danish press, represented by the largest Danish newspaper, Jyllands-Posten, and evidence regarding consequences for consumer perceptions about, attitudes towards and demand for organic food. Organic food products are considered environ-

\footnotetext{
${ }^{6}$ See http://www.oilspill.state.ak.us/facts/

${ }^{7}$ The press coverage is well documented on Bjørn Lomborg's homepage, http://www.lomborg.com/. His homepage also contains a link to the critique in Scientific America.
} 
mentally superior to conventional ones as they are produced without the use of pesticides and chemical fertilizers. Hence, the production process leads to less pollution and is typically also less energy intensive than conventional, industrialized farming. In Denmark, it is not allowed to sell food products as organic unless the farm is certified as such by the authorities. Certified organic products are labeled. The number of organic farms in Denmark has grown by more than 700 per cent and the organically farmed area more than 800 per cent ${ }^{8}$ during the I990s (Jacobsen, 200I).

The best selling organic food products in Denmark are fresh milk and oatmeal, which have both captured a market share of above 25 per cent. Organic eggs, pasta and vegetables sell quite well too, but organic meat products, with market shares below 2 per cent, have not been successful. ${ }^{9}$ A high growth in the Danish market of organic food products during most of the I990s waned at the end of the decade, and since the turn of the millennium there has been a negative trend in the market for many products (Danmarks Statistik, 200I; Thulstrup et al., 2002; Wier, 2001). ${ }^{\text {I0 }}$

Of course, no single factor can be held responsible for the growth and subsequent stagnation and decline in the market for organic food products in Denmark. However, some of the most obvious candidates, such as market saturation and increased competitiveness of conventional food products in terms of price and/or quality, can be rejected. With a share of only 5.6 per cent of the overall food market and the huge diversity of market shares for individual products it seems unlikely that the market for organic food is saturated. The comparative product-level price indexes published on the web page of Organic Denmark shows that relative prices are somewhat volatile and follow individual paths, but that a longterm overall tendency to reduce the price premium for organic food products persists, albeit at a reduced pace, since the turn of the millennium. ${ }^{\text {II }}$ As regards the perceived quality of Danish conventional food products, there is no evidence that this has changed during the last decade.

In the absence of better explanations - and given the documented influence of the media on the public's perception of environmental issues - it seems reasonable to suspect that the way the media has treated news about organic food products and producers could be one of the factors involved in the souring of the organic market. Two types of change in the media's coverage of the organic issue could account for the change from growth to stagnation in the organic market at the turn of the millennium. First, if the organic issue was seen as highly newsworthy in the early I990s, but lost newsworthiness in the late I990s, the waning growth in the organic market could be the (partial) result of lost free PR (public relations), which would be equivalent to a large cut in the sector's advertising budget. Second, due to boredom with the traditional way of framing the organic issue among news editors (see Brown and McDonald, 2000), competing - and therefore new and perhaps even dramatic - framings of the issue may have enjoyed increased newsworthiness. For example, competing framings might be provided by conventional (industrialized) agriculture and its organizations. And perhaps in particular because the organic sector is not only governed by rules and principles, but also enjoys an image of moral superiority, cases where companies break the rules - for profit or just by accident - is easily framed as a scandal: a very newsworthy phenomenon (Kepplinger, 200I). If the organic sector is increasingly getting negative publicity due to competing framings of the issue being more newsworthy and journalists actively looking for scandals in the sector, this could seriously undermine the trust in organic products. Moreover, because of the credence character of the organic attribute, trust is imperative for the sale of organic food products (see, e.g., Bech-Larsen and Grunert, 200I).

According to the agenda-setting literature cited above, we should expect that a change in the media agenda for the organic food issue, either at the first (i.e. news editors' perception of the newsworthiness

\footnotetext{
${ }^{8}$ Occupying approximately $6 \%$ of total farmland at the turn of the millennium.

${ }_{9}^{9}$ See http://www.alt-om-okologi.dk/

${ }^{\text {Io }}$ For the most recent years, see http://www.alt-om-okologi.dk/

${ }^{\text {II }}$ See http://www.alt-om-okologi.dk/
} 
of the issue in general) or the second level (i.e. their preferred framing of the issue), would influence the public's perception of the importance of the organic food issue. Perceived issue importance, or concern, has been found to have behavioral implications (see, e.g., Thøgersen and Ölander, 2006). Communication (see, e.g., Devine and Hirt, I989) and social marketing research (see, e.g., Ellen et al., I99I; Fishbein and Yzer, 2003) suggest that mass-mediated information influences behavior mediated through other psychological constructs, such as the consumer's attitude towards (in this case) buying organic food and faith in the individual's own contribution making any difference (termed 'perceived consumer effectiveness'; see Ellen et al., I99I). Hence, in order to detect the influence of the media agenda on behavior it is relevant to investigate how it influences mediating psychological constructs such as these.

\section{Data}

Because of the widespread duplication of stories across different media, I relied on a single, high-quality, general-purpose media source. I used the largest Danish newspaper, Jyllands-Posten, as my media source because it has national coverage and belongs to the category of general purpose, quality broadsheet newspapers. Among other things, it contains an ambitious daily business section and a weekly consumer section. In addition, it has an on-line searchable electronic archive of everything it has published since January I996, which makes the retrieval of relevant news items for analysis much more convenient. In October 2002, I performed a search using the Danish words for 'organic' and 'organic producer' as search terms. After excluding advertisements, letters to the editor and articles not really dealing with the organic issue (at least not in any way meaningful to this context), the search produced a hit of 333 independent news items of varying length and prominence in the newspaper.

I only made a rather crude content analysis of these news items. ${ }^{\mathrm{I2}}$ Neither the length nor the prominence of the news item in the paper was taken into account. I only counted the number of news items on organic issues each year and classified the items in three groups: (I) news items with a positive and/or optimistic framing of organic products, producers or the sector as a whole, (2) news items with a negative and/or pessimistic framing of the issue and (3) news items with a neutral or non-classifiable framing of the issue.

Figure I shows the number of news items in Jyllands-Posten dealing with organic issues each year from 1996 to 2002 as well as the share of these classified in group I and group 2 .

According to Figure $\mathrm{I}$, there is not a clear long-term trend in the number of news items regarding organic issues appearing in Jyllands-Posten in the period. Hence, if this result is representative for Danish news media, a decline in media attention as such cannot explain the negative trend in the organic market in recent years. However, the valence of the favorite framing of the issue changed dramatically. Although the newspaper's coverage of organic issues was ambivalent in the whole period, from being predominantly positive and optimistic at the beginning of the period, the framing became increasingly negative and pessimistic and the negative and pessimistic framing has been dominating since the turn of the millennium.

Is this change in the framing of organic issues a reflection of objective events, or is it due to idiosyncratic editorial imperatives, such as boredom with traditional ways of framing the issue, making the competing framing relatively more 'competitive'? Relevant changes in objective events would be that negative (e.g. about misconduct or fraud) and pessimistic events (e.g. about dwindling markets) became

\footnotetext{
${ }^{\text {I2 }}$ Notice that only one coder (myself) made the content analysis. In order to be able to document the reliability of the classifications, it would have been better with several independent coders. However, this is a very simple content analysis, which means that the risk of coding error is fairly low, as reflected in reported inter-coder reliabilities of 90\% or above in similar studies (e.g. Bansal and Clelland, 2004; McCombs et al., I997).
} 


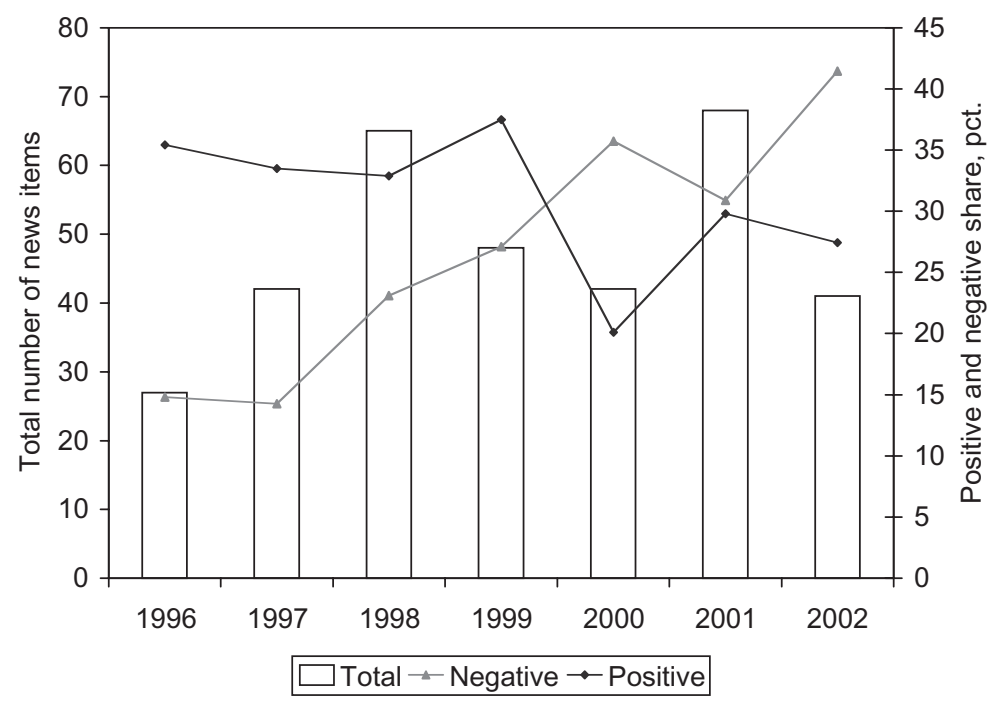

Figure 1. Articles about organic food products, producers or the organic sector in Jyllands-Posten 1996-2002. Source: Jyllands-Posten's electronic archive

relatively more abundant over this period. However, the evidence speaks against this explanation of the change in framing. In the years I999 to 2002, between I.8 and 3.I per cent of the controlled companies in the Danish organic food sector had violated rules, down from I3.3 per cent in I994 (Fødevaredirektoratet, 2003). Hence, the relative frequency of such events at least did not increase over the period, although the absolute number might have. However, judged from the number of news items in Jyllands-Posten reporting violations of the rules in the organic sector it did not: I996, 0; I997, I; I998, 3; I999, 3; 2000, I; 200I, 3; 2002, 3. As regards market prospects in the Danish organic sector, it was reported above that it turned sourer after the change of the millennium. However, it is obvious from Figure I that the change towards a negative and pessimistic framing preceded the change in market prospects. In sum, objective events can hardly explain the change in the dominating framing of organic issues in Jyllands-Posten, leaving us with editorial preferences as the most likely explanation for the change in the framing of news about organic products and production.

As mentioned previously, changes in the media agenda, such as the one reflected in Figure I, do not influence consumer behavior in a direct way. Rather, the behavioral influence is mediated through psychological constructs, such as issue importance or concern (e.g. concern about pollution from the use of pesticides and fertilizers in agriculture), faith in one's individual contribution making any difference (i.e. perceived consumer effectiveness) and/or the attitude to buying organic food products. Hence, it is proposed here that the more hostile media agenda from the late I990s onwards has had a negative influence on consumer attitudes and perceptions regarding organic food, and that it is due to negative changes in these psychological constructs that consumers are less keen to buy organic food products.

Three national surveys that were collected by my research group around the turn of the millennium lend partial support to this proposition (see Table I). Respondents are random samples of Danish consumers interviewed by telephone. In contacted households the interviewee was picked randomly among individuals 18 years of age or older (next birthday method). ${ }^{\mathrm{I}}$

${ }^{13}$ A professional marketing research company, Jysk Analyseinstitut, carried out the interviews. The response rate was only measured in the first interview, where it was $58 \%$. 


\begin{tabular}{|c|c|c|c|c|c|}
\hline Buy organic & 2.27 & 2.22 & 2.00 & -0.74 & -3.32 \\
\hline$N$ & 1040 & 285 & 251 & & \\
\hline Attitude $^{2}$ & 1.98 & 2.09 & 2.25 & 1.74 & 3.47 \\
\hline $\begin{array}{l}\text { Concern, the use of pesticides and } \\
\text { artificial fertilizers in agriculture }\end{array}$ & 1.82 & 1.93 & 2.07 & 1.65 & 3.27 \\
\hline$N$ & 1069 & 306 & 267 & & \\
\hline Perceived effectiveness ${ }^{4}$ & 3.77 & 3.68 & 3.60 & -1.23 & -2.00 \\
\hline
\end{tabular}

Table 1. Buying organic food, attitude towards buying organic food, concern about pollution from pesticides and artificial fertilizers and perceived effectiveness regarding influencing such pollution, Denmark 1998, 1999 and 2000

'Measured by three questions of the type 'How often do you buy organic X,' where $\mathrm{X}$ refers to a specific product (milk, minced beef and frozen peas), and using a five-point scale with the labels 'never', 'rarely', 'half the time', 'often' and 'always/every time'. A higher score indicates more frequent purchase of organic food products. Cronbach's alpha: $0.73,0.74$ and 0.76 .

${ }^{2}$ The attitude towards buying organic milk, measured on a three-item five-point semantic differential scale with the end points meaningful-meaningless, right-wrong and beneficial-harmful. A higher score indicates a less positive attitude. Cronbach's alpha: $0.80,0.80$ and 0.86 .

${ }^{3}$ As part of a battery consisting of ten social issues, measured on a four-point scale with the levels 'very concerned', 'somewhat concerned', 'a little concerned' and 'not concerned'. A higher score reflects lower concern.

${ }^{4}$ Measured by means of two items: 'the individual citizen cannot do much about the use of pesticides and artificial fertilizers in agriculture' (reversed) and 'every little contribution from consumers help to reduce the use of pesticides and artificial fertilizers in agriculture', on a five-point scale with the end points 'totally disagree' and 'totally agree' and coded so that a higher number indicates higher perceived effectiveness. Cronbach's alpha for the combined measure in the three waves is $0.61,0.57$ and 0.61 , respectively. ${ }^{5} t$-values $>|1.96|$ are statistically significant, $p<0.05$.

Table I reports means of self-reported buying behavior and a number of psychological variables concerning organic food, measured in independent random samples of Danish consumers at three points in time: November-December I998 and one and two years later. All indicators reported in the table reflect a weak, but persistent tendency in a negative direction for organic food. None of the changes are statistically significant when comparing only the first two measurements, but all of them are when the first and the third measurement are compared. Hence, the results in Table I are consistent with other sources, cited above, reporting that the growth in Danish consumers' purchase of organic food during the I990s ended with the decade and turned into a weak, but persistent decline. Further, and consistent with the changes in the media agenda reported in Figure I, Danish consumers became less concerned about pollution from pesticides and chemical fertilizers and they lost some of their faith in the contribution of an individual consumer making any difference in this connection (i.e. reduced perceived consumer effectiveness). Consistent with the rest of the evidence, Danish consumers' attitudes towards buying organic food products became less positive in this period. That these perceptions, attitudes and buying behavior change in concert with the media agenda is, of course, no proof of a causal relationship. But it is at least consistent with the suggested theoretical propositions.

\section{Discussion}

Environmental protection has indeed been an issue with remarkable staying power on the public agenda in Europe and North America in the past two to three decades (Dunlap, 2002), and many companies 
have prospered by seizing the opportunities offered by the growing 'green' market (Peattie, I995). However, whereas already in the I990s there were signs of a consumer 'backlash' against green marketing (Crane, 2000; Wong et al., I996), one now gets the feeling that a general 'counter-attack' is being orchestrated against the promotion of the environmental cause by the news media. A well known example is the embracement by influential media in Europe and North America of the Danish political scientist Bjørn Lomborg's book The Skeptical Environmentalist, which attacks a number of established 'truths' about environmental problems. In this paper, I have reported evidence regarding the rather successful Danish organic food sector showing that the news media's assessment of what is newsworthy does not only mean that this particular 'green' business has lost the current of a rising issue-attention cycle. In addition, what may be nothing more than boredom with reporting its successes has meant that positive stories about the organic issue have lost newsworthiness while negative stories have become more newsworthy. This is just one specific case, of course. However, it illustrates a general point about the placement of green issues on the media agenda. Operating in a highly competitive market, news editors fear that their audiences (customers) get bored with the news they are bringing (their products). Hence, they search for news items that can be cast in new and/or dramatic ways. Of course, there are limits to how far one can generalize from a single case study and there is definitely a need for replications, both in the same and in different contexts. But this particular case study supports other evidence suggesting that 'green' businesses now find themselves in a much more hostile environment than a decade ago (e.g. Brown and McDonald, 2000; Crane, 2000). The time seems to have passed where an environmentally improved product was newsworthy and, hence, attracted media interest and free PR. However, 'green' product failures involve a sense of drama, and misconduct in businesses with a green image has a taste of hypocrisy, both of which add to the newsworthiness of an event. Unfortunately, as illustrated by the Danish organic food case, a negative and pessimistic framing may be a self-fulfilling prophecy. It may make consumers lose trust (especially news about misconduct) and faith (news about dwindling markets) in 'green' products, which has been shown to have a negative influence on their purchase of such products (Bech-Larsen and Grunert, 200I; Wiener and Doescher, I99I). Furthermore, the worsening of the business climate may convince managers that it is best to lower one's green profile (see, e.g., Crane, 2000). As a result, the downward trend in issue attention and in the market for 'green' products is likely to be further amplified.

\section{References}

Ader CR. I995. A longitudinal study of agenda setting for the issue of environmental pollution. Journalism and Mass Communication Quarterly 72: 300-311.

Anderson A. I997. Media, Culture and the Environment. UCL Press: London.

Attrup L. 2000. Fiasko for dyrt velfærdskød [Failure for expensive welfare meat]. Jyllands-Posten 7 February: I.

Bansal P, Clelland I. 2004. Talking trash: legitimacy, impression management, and unsystematic risk in the context of the natural environment. Academy of Management Journal 47: 93-103.

Bech-Larsen T, Grunert KG. 200I. Konsumentscheidungen bei vertrauenseigenschaften: eine untersuchung am beispiel des kaufes von ökologischen lebensmitteln in Deutschland und Dänemark. Marketing ZFP 23: I88-I97.

Behr RL, Iyengar S. I985. Television news, real-world cues, and changes in the public agenda. Public Opinion Quarterly 49: $38-57$.

Bennulf M. I999. Miljöengagementet i graven? [Environmental involvement in the grave?] In Livsstil och Miljö. Värderinger, Val, Vanor, Lundgren LJ (ed.). Naturvårdsverket: Stockholm; 87-104.

Brosius H-B, Kepplinger HM. I990. The agenda-setting function of television news: static and dynamic views. Communication Research I7: I83-2II.

Brosius H-B, Kepplinger HM. I992. Linear and nonlinear models of agenda-setting in television. Journal of Broadcasting and Electronic Media 36: 5-23. 
Brown P, McDonald F. 2000. Have we 'had enough of all that eco-bollox'? In The Daily Globe. Environmental Change, the Public and the Media, Smith J (ed.). Earthscan: London; 65-78.

Chan K. I999. The media and environmental issues in Hong Kong I983-95. International Journal of Public Opinion Research II: $135-$ I5I.

Crane A. 2000. Facing the backlash: green marketing and strategic re-orientation in the I990s. Journal of Strategic Marketing 8: $277-296$.

Danmarks Statistik. 200I. Flere Familier Køber Økologiske Varer [More Families Buy Organic Products], Nyt fra Danmarks Statistik 404. Danmarks Statistik: Copenhagen.

Dearing JW, Rogers EM. I996. Agenda-Setting. Sage: Thousand Oaks, CA.

Devine PG, Hirt ER. I989. Message strategies for information campaigns: a social psychological analysis. In Information Campaigns: Balancing Social Values and Social Change, Salmon CT (ed.). Sage: Newbury Park, CA; 229-259.

Downs A. I972. Up and down with ecology - the 'issue-attention' cycle. The Public Interest 28: 38-50.

Dunlap RE. 2002. An enduring concern. Public Perspective September/October: IO-I4.

Dunlap RE, Scarce R. I99I. The polls-poll trends: environmental problems and protection. Public Opinion Quarterly 55: $65 \mathrm{I}-672$.

Dunwoody S, Griffin RJ. I993. Journalistic strategies for reporting long-term environmental issues: a case study of three superfund sites. In The Mass Media and Environmental Issues, Hansen A (ed.). Leicester University Press: Leicester; 22-50.

Ellen PS, Wiener JL, Cobb-Walgren C. I99I. The role of perceived consumer effectiveness in motivating environmentally conscious behaviors. Journal of Public Policy and Marketing Io: IO2-II7.

Fishbein M, Yzer MC. 2003. Using theory to design effective health behavior interventions. Communication Theory 13: I64-I83.

Fødevaredirektoratet. 2003. Notat om Kontrollen med Økologiske Fødevarer 2002 [Note About the Control of Organic Food Products 2002]. Fødevaredirektoratet: Copenhagen.

Hansen A. I993. Greenpeace and press coverage of environmental issues. In The Mass Media and Environmental Issues, Hansen A (ed.). Leicester University Press: Leicester; I50-I78.

Henry GT, Gordon CS. 200I. Tracking issue attention. Specifying the dynamics of the public agenda. Public Opinion Quarterly 65: I57-I77.

Hilgartner S, Bosk CL. I988. The rise and fall of social problems: a public arenas model. American Journal of Sociology 94: $53-78$.

Hofrichter J, Reif K. I990. Evolution of environmental attitudes in the European Community. Scandinavian Political Studies I3: $119-\mathrm{I} 46$.

Iyengar S, Kinder DR. I987. News that Matters. University of Chicago Press: Chicago, IL.

Jacobsen L-B. 200I. Potentialet for Økologisk Jordbrug. Sektor og Samfundsøkonomiske Beregninger [The Potential for Organic Farming. Sector and Macro Economic Calculations], Report I2I. Statens Jordbrugs- og Fiskeri-økonomiske Institut: Frederiksberg.

Kepplinger HM. 200I. Die Kunst der Skandalierung und die Illusion der Wahrheit. Olzog: München.

Kramer C. I998. Umweltbewußtsein in Europa - ähnliche probleme, unterschiedliches Verhalten. Informationsdienst Soziale Indikatoren (Heft 20), IO-I4.

Linné O. I993. Professional practice and organization: environmental broadcasters and their sources. In The Mass Media and Environmental Issues, Hansen A (ed.). Leicester University Press: Leicester; 69-80.

Lomborg B. 200I. The Skeptical Environmentalist. Cambridge University Press: Cambridge.

MacKuen MB, Coombs SL. I981. More than News: Media Power in Public Affairs. Sage: Beverly Hills, CA.

McCarthy JD, McPhail C, Smith J. I996. Images of protest: dimensions of selection bias in media coverage of Washington demonstrations, I982 and I99.. American Sociological Review 6r: 478-499.

McCombs M, Llamas JP, Lopez-Escobar E, Rey F. I997. Candidate images in Spanish elections: second-level agenda-setting effects. Journalism and Mass Communication Quarterly 74: 703-7I7.

McCombs M, Shaw DL. I972. The agenda-setting function of the mass media. Public Opinion Quarterly 36: I76-I85.

O'Donovan M. 2003. Atlantic tanker disaster. The anatomy of response. Environment for Europeans I3: 5-6.

Pakulski J, Tranter B, Crook S. I998. The dynamics of environmental issues in Australia: concerns, cluster, and carriers. Australian Journal of Political Science 33: 235-252.

Peattie K. I995. Environmental Marketing Management: Meeting the Green Challenge. Pitman: London.

Poulsen U. I999. Den politiske forbruger - et fata morgana [The political consumer - a fata morgana]. Kristeligt Dagblad I8 August: 7 .

Rogers EM, Dearing JW, Bregman D. I993. The anatomy of agenda-setting research. Journal of Communication 43(2): 68-84. Soroka SN. 2002. Issue attributes and agenda-setting by media, the public, and policymakers in Canada. International Journal of Public Opinion Research I4: 264-285. 
Sønderriis E. I997. Glade grise og god samvittighed [Happy pigs and a good conscience]. Information 2-3 August: 4.

Thulstrup J, Rassing C, Madsen LH. 2002. Danskerne 2003. Mellem Velfoerd og Afmagt [The Danes 2003. Between Welfare and Powerlessness]. Institut for Konjuntur-Analyse: Copenhagen.

Thøgersen J, Ölander F. 2006. To what degree are environmentally beneficial choices reflective of a general conservation stance? Environment and Behavior. 38.

Vestergaard M. I998. Øko-salg halter [The organic sale is limping]. Information 5 January: I.

Weaver D, McCombs M, Shaw DL. 2004. Agenda-setting research: issues, attributes, and influences. In Handbook of Political Communication Research, Kaid LL (ed.). Erlbaum: Mahwah, NJ; 257-282.

Wiener JL, Doescher TA. I99I. A framework for promoting cooperation. Journal of Marketing April: 38-47.

Wier M. 200I. Markedspotentiale og merpriser [Market potential and premium prices]. In Økonomiske Perspektiver for Økologisk Jordbrug, report I24, Christensen J, Frandsen SE (eds). Statens Jordbrugs- og Fiskeriøkonomiske Institut: Copenhagen.

Wong V, Turner W, Stoneman P. I996. Marketing strategies and market prospects for environmentally-friendly consumer products. British Journal of Management 7: 263-28I.

Zucker HG. 1978. The variable nature of news media influence. In Communication Yearbook, Vol. 2, Ruben BD (ed.). Transaction: New Brunswick, NJ; 225-245. 